Karagöz, B. (2017). Naki Tezel’in Türk Masalları adlı kitabının değerler açısından analizi. Ana Dili Eğitimi Dergisi, $5(3), 534-556$.

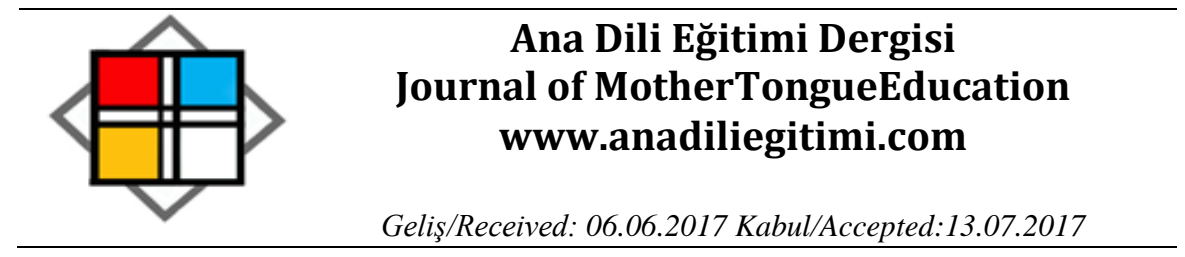

\title{
Naki Tezel’in Türk Masalları Adlı Kitabının Değerler Açısından Analizi
}

\author{
Beytullah KARAGÖZ*
}

Öz

Bu araştırmada Naki Tezel'in Türk Masalları adlı eserindeki değerleri, Schwartz Değer Ölçeği'ne göre sınıflandırmak ve eserin değerler eğitimi sürecindeki önemini belirlemek amaçlanmıştır. Bu araştırma nitel araştırma geleneğine dayalı betimsel bir araştırma olup, araştırmanın verileri döküman incelemesi yoluyla toplanmıştır. Elli dört masalın bulunduğu eserdeki değerler Schwartz Değer Ölçeği'ne göre sınıflandırılmış, verilerin analizinde betimsel analiz yaklaşımı tercih edilmiştir. Çalışma sonucunda Türk Masalları adlı eserde en çok yer alan değer gruplarının geleneksellik(118) ve özyönelim(116) olduğu belirlenmiştir. Bu değer gruplarını sırasıyla iyilikseverlik(83), güç(75), başarı(74), hazcılık(73), uyarılım(45), uyma(40), güvenlik(25) takip etmektedir. Eserde en az rastlanan değer grubunun evrenselcilik(10) olduğu görülmüştür. Geleneksellik ve özyönelim değer grubuna en yoğun olarak Kırk Kardeş(16), Altın Bülbül(11), Kısmetimi Arıyorum(10), Kara Kedi(7), Kırkıncı Oda(7) adlı masallarda yer verildiği ortaya çıkmışır. Evrenselcilik değer grubuna ait değer ifadelerinin ise Sihirli Yüzük (2) ve Kırkıncı Oda (2) adı masallarda yer aldığı belirlenmiştir.

Anahtar Kelimeler: Naki Tezel, Türk Masalları, Değerler, Schwartz Değer Ölçeği

\section{Analysis Of Naki Tezel's Book Türk Masalları (Turkish Tales) in Terms of Values}

\section{Abstract}

The aim of this research is to classify the values in Naki Tezel's work "Türk Masalları",using the Schwartz Value Scale and to determine the importance of the work in the process of teaching values. This research is a descriptive study, conducted in the qualitative research tradition, and the data were collected, using document review. The values inthe fifty four tales in the book were classified, using the Schwartz Value Scale, and the descriptive analysis approach was preferred in the analysis of the data.At the end of the analysis, it was determined that the most prevalent value groups in the work Türk Masalları were tradition (118) and self-direction (116). These values were followed by benevolence (83), power (75), achievement (74), hedonism (73), stimulation (45), concordance (40), and security (25). It was found that the least-seen value group in the work was universalism (10).Tradition and self-direction value groups were mostly found in the talesKırk Kardeş (16), Altın Bülbül (11), Kısmetimi Arıyorum (10), Kara Kedi (7), Kırkıncı Oda (7). It was found that the value expressions, belonging in the universalism value group were included in the tales Sihirli Yüzük (2) and Kırkıncı Oda (2).

Keywords: Naki Tezel, Turkish Tales, Values, Schwartz Value Scale

\footnotetext{
${ }^{*}$ Yrd. Doç. Dr. Gaziosmanpaşa Üniversitesi, Eğitim Fakültesi, Türkçe ve Sosyal Bilimler Eğitimi Bölümü, beytullah.karagoz@gop.edu.tr.
} 


\section{Giriş}

Bugünün dünyasında birey-toplum yaşamında meydana gelen gelişim ve ilerleme yaşamın tüm katmanlarını etkilemektedir. Bu bağlamda gündelik yaşam, aile, toplum, çalışma yaşamı gibi bireyin dolaylı yahut dolaysız etkilendiği dış unsurlar sürekli ve hızlı bir değişim geçirmektedir. Bilimsel ve teknolojik gelişmelerin toplumları dönüştürdüğü, kültürel kimlikleri erozyona uğrattığı bilinen bir gerçekliktir. Bu süreçte toplumların kendi olarak kalabilmeleri, varlıklarını geleceğe taşıyabilmeleri için eğitim oldukça önemlidir.

Eğitim ilerlemenin, demokrasinin erdemine inanmış bir ulus olabilmenin, toplumun ana unsuru insanı bilgi, beceri bağlamında yetkin kılmanın en temel aracıdır. Eğitim bireyin öz kültürüne/kimliğine sahip çıkarak var olmasını sağlar. Bu nedenle öğrenim çağına gelmiş her bireyin uygun ahlaki kararlar ve davranışlar sergilemesine yardımcı olacak becerilerle donatılması kaçınılmaz olarak okulların temel hedefleri arasındadır (Ekşi, 2003). Bu amaca ulaşma yolunda değerlerin önemi büyüktür.

Değerler insanlarla varlığını sürdüren ve insana özgü olup geleceğe aktarılan inanışlar olarak insanın inşa ettiği bir bağlamda bireyin soyut ve ruhsal boyutuna işaret eder. Aydın (2003), Theodorson'dan aktarımla değeri "sosyal olguların önemliliği üzerindeki değerlendirmede, özel eylemleri ve amaçları yargılamada temel ölçü sağlayan ve bir grubun üyelerinin güçlü duygusal bağlarıyla oluşmuş soyut, genelleştirilmiş davranış prensipleri" olarak görür. Bolay (2007), değerin "arzu edilen, ilgi duyulan, ihtiyaç duyulan şey ve 'olması gereken'” durum olduğu üzerinde durur. Halstead ve Taylor (2000: 169) için değer,"davranışa ilişkin genel rehber olarak hareket eden ilkelere ve temel inançlara, belirli eylemlerin iyi veya arzulanan standartlarına atıfta bulunmak için kullanılan gerçekliklerdir."'Değerler, hayatımıza önem veren, seçtiğimiz önceliklerle yansıtılan, sürekli ve tekrar tekrar kendilerine göre hareket etmemiz gereken fikirlerdir"(Hall, 2003). Sapsağlam (2017: 7) değerleri manevi olanla yakından ilişkili anlamsal bir seçme işlemine ölçüt oluşturan kurallar olarak değerlendirir.

Değer, insanın ahlaki seçimlerine ilişkin zemin oluşturan temel yargılardır. Bireyin neyin iyi neyin kötü olduğu konusunda bilinç kazanmasına yardımcı olur. Bu bakımdan insan davranışının kökeninde değerler olduğu, değerlerin kişiyi “iyi, doğru, güzel olan”a yönlendirdiği, bu yargılarla insan yaşantısının anlam kazandığı düşünülebilir. Bununla birlikte değer, insanı insan yapmaya ve insanı diğer canlılardan ayırmaya (Ulusoy ve Dilmaç, 2012), bireyin kişi, varlık, olay, durum karşısında duyarlık ortaya koymasına (Yaman, 2012), ontolojik açıdan anlam krizini çözmeye (Kuçuradi, 1998), insanın kimliğine ve eylemlerine anlam kazandıran bir çerçeve oluşturmasına (Hökelekli, 2011: 265),yeni yetişen nesillerin dünyasını ve geleceği kurmaya (Kaymakcan ve Meydan, 2012 olanak tanır. 
Değerlerin tanım ve işlevleri ortak bir çerçeve etrafında buluşturulurken bu noktada değerlerin sınıflandırılması problemi ortaya çıkar. Sınıflandırma bağlamında değerleri Spranger (1928) altı, Rokeach (1973) iki, Schwartz ise on grupta toplamıştır. Spranger değerleri altı gruba ayırmıştır. Bunlar "bilimsel değerler, ekonomik değerler, estetik değerler, sosyal değerler, politik değerler ve dinî değerlerdir" (Güngör, 2010: 84-85). Rokeach (1973) ise, iki grupta toplamıştır. Bunlar amaç değerler (Terminal values) ve aracı değerlerdir (Instrumental values).“Yaşamın temel amaçlarını gösteren değerleri amaç değerler, bu amaçlara ulaşmak için kullanılacak davranışları ise araç değerler olarak tanımlamıştır" (Beldağ, 2012: 15). Schwartz ise değerleri güç, başarı, hazcllık, uyarılım, özyönelim, evrenselcilik, iyilikseverlik, geleneksellik, uyma, güvenlik gibi on farklı başlık çerçevesinde ele almıştır. Bu on değerin altında her değer için elli altı alt değer başlı̆ı yer almaktadır.

Değerlerle ilgili pek çok sınıflandırma çalışması olmasına karşın, en çok kullanılan ve en gelişmiş değer teorisi Schwartz'ın geliştirdiği değer sınıflamasıdır. Schwartz insanı çevreleyen bir yapıya dayalı teorik temelli bir değer tasnifi geliştirerek değer ölçümlerini geliştirmede büyük adımlar atmıştır (Parks ve Guay, 2009).

\section{Masal ve Değerler}

1915 yılında İstanbul'da doğan ve 1980'de İstanbul'da yaşamını yitiren Naki Tezel Anadolu'nun çeşitli yörelerinde yaygın olarak söylenen masalları derleyerek yazılı kültür birikimine kazandıran ünlü bir halkbilimcidir. 1933-1958 yılları arasındaki çabanın ürünü olan Türk Masalları adlı kitap, 54 masaldan oluşmaktadır. Masallarda; peri kızı, cadı karı, kıııın içinden çıkan on arap dev, peynir tulumu suretine bürünme, devler ve dev anaları, kedi suretine bürünme, yedi canlı arap, ağladıkça gözlerinden inciler dökülen ve güldükçe yanaklarında güller açan güzel kız, Hızır Dede, güvercin suretinde ortaya çıkma, senede bir tane yetişen kıymetli elma, konuşan tavşan, altın kuş, konuşan güvercin, Keloğlan'ın Ali Cengiz'den kaçarken farklı şekillere girmesi gibi olağanüstülükler olduğu görülmüştür.

Masal, halkın yaratıcı söylemi ve dilsel zenginliğyle üretilmiş anlatılardır. Güney (1971: 87), masalın toplumun hayal gücüyle yaratılmış sözlü verimler olduğunu vurgularken Elçin (1993: 368) ise bilinmeyen bir yerde, bilinmeyen şahıslara ve varlıklara ait hadiselerin macerası, hikâyesi olarak niteler.

Masallar insanın hayat ve tabiat karşısındaki tavrını, duygu, sezgi ve düşüncelerini dile getirir. İnsanın tabiatla mücadeleye başladığı dönemin olağanüstü unsurları masallara vücut vermiştir. Dolayısıyla masallarda eski kültürlere, dinlere ve törelere ait motiflere sıkça rastlanır. Bir ülkenin herhangi bir yöresinde anlatılan bir masal az çok farklılıklarla o ülkenin başka yörelerinde de anlatılır. Hatta bir ülkeye ait bir masalın bazı motif ve unsurlarla başka ülkelerde de anlatıldığı görülür. Bu 
durumdaki masallar, millî ve evrensel değerlerin genç kuşaklara aktarmada, eğitimcilere uygulamada kolaylık ve yarar sağlayacak, onların eğitim ortamlarında kullanılma gerekçesi ve yöntemini belirleyecektir (Karatay, 2007). Küçük çocukların dikkatini, ilgisini yalnızca masallar çektiği için, folklor malzemesi olarak derlenen masallardan, açık bir anlatım, basit ve kısa cümlelerle yazılmış, eğitici ve "kıssalı" hikâyeler yazmak, kötü unsurları atıp, çocuk hayalini işletecek iyi unsurlarla güzel masallar hazırlamak, çocuk edebiyatına büyük hizmet olur (Tezel, 2014).

Çocuk edebiyatının kaynaklarından olan masal çocuğun psikososyal gelişimi, dil ve edebiyat duygusu, kişilik ve düşünce eğitimi bağlamında öncelikli rol oynar. Kültürel beslenme kaynağı işlevi görerek yeni yetişen kuşaklara anadilin sıcaklığını duyumsatır, onları Türkçenin zengin anlatım olanaklarıyla buluşturur. Masallarla tanışan çocuklar dil sevgisi ve özeni kazanır, kültürel ve tarihsel bilgi kaynaklarına yönelir, insana ve yaşama ilişkin doğrular ile tanışır. Çocuk duyarlığını en iyi yansıtan bu tür, çocukta iyilik arzusunun oluşmasına, karşıtların birliğinin tanınmasına, iyiliğin, güzelliğin ve doğruluğun üstünlüğünün onaylanmasına zemin hazırlar (Şimşek, 2005: 75). Bu yolla değerleri yaşamlarının temeli görerek ruh köklerine duyarlı bireyler yetiştirme ideali gerçeklik kazanabilir.

Masallarda geçmişin; günlük yaşam işleyişi, aile yaşantısı, bayramları, düğünleri, büyükler ve küçükler arasındaki iletişim, eğitim şekilleri, yemek alışkanlıkları, çevre ile ilişkileri vb. davranış yapıları (Sever vd., 2015) anlatılırken; öte yanda insanın ve içinde yaşadığı toplumun duygu durumu dillendirilir. Bu kapsamda Günay (1992), masallarda talihsizlik ve aksiliklerin bir kere ortaya çıkacağını, bu sorunlar aşıldıktan sonra iktidar, başarı ve mutluluğun simgesi taç ve evliliğe hiçbir zararın dokunmayacağını kaydeder. 'Onlar ermiş muradına, biz çıkalım tahtına' tekerlemesinin sağlık, huzur ve esenliği sembolize ettiğini belirtir.

Değer bilinciyle donanmış bir toplum olma yolunda masalların rolü son derece önemlidir. Masal gerçek dünyanın basitleştirilmiş bir modeli gibidir. Aynı zamanda da çocuğun dünyaya ilşikin bilgileri ve deneyimleri edinmesinde yardımcı bir araçtır (Dilidüzgün, 2007: 26). Masallar geçmişte atalarımızın yaşadıkları olayları, acı ve üzüntüleri sanatsal biçimde bugüne aktarır. Bilinç aşısı yaparak kültürel zenginliklerin farkına varmayı, onlara sahip kuşaklar yetişmesini sağlar. Büyüklerin dilinden dökülen bu birikimler; tarihsel planda bir anlam dizgesi kazandırarak gidilecek yönü gösterir ve kimlik oluşturmaya olanak tanır.

Anadili eğitiminde masallar öğrencinin anlama ve anlatma becerileri konusunda bilgi, deneyim kazanmasını, duygu ve düş evrenine yeni değerler katmasını sağlar. Çocuklara masal okurken çocuğun iç dünyasına, yargılarına, kişilik ve kimliğine, entelektüel ilgilerine derinlik kazandırılır. Bu yaklaşımla ulusal kültürün manevi bir boyutu olan değerler, ortak düşünceler 
geliştirmenin aracı olur. Çocuğa tarihsel mirasa sahip çıkmanın önemini, ulusunu ve ülkesini sevmenin onurunu anımsatır. Böylece kültürünü özümsemiş bireylerin edindiği kuramsal bilgileri davranışa dönüştürmesi için bir yaşantı kesiti oluşturur.

Öztürk (2005: 42) masal gibi insanlığı birbiriyle kaynaştıran sözlü anlatı ürünlerinin bireyin değerlere yönelik yaklaşımını oluştururken aynı biçimde arka planda toplumun değer yargılarını meydana getirdiğini vurgular. Halkın yaratıcı kültür ürünleri geçmiş dönemlerin bilgi, beceri ve deneyimleri üzerinde yükselen eğitsel gereçlerdir. Erken dönemden başlayarak bu kültür birikimiyle tanışan çocuklar iç dünyalarını zenginleştirebilir. Masallarla çocuklar arasında kurulan etkileşim, çocukta sanatsal zevki yükselterek yaşam ve insan gerçekliğine ilişkin dilsel kanıtlar sunar. Bu çerçevede tasarlanmış amaçlı bir etkinlik olan eğitimde, çocuğun düşünce kaynaklarını besleyen masallar değerler eğitimine kültürel bir içerik sağlamış olur. Arıcı (2016) da masalın bireyin dili özenli, düzgün, doğru kullanma yetilerini geliştirme, iyi insan olma, doğa bilinci kazanma konularında olduğu gibi, duygu ve düşünce evrenini zenginleştirme bağlamında etkili olduğuna işaret eder.

Yukarıda belirtilen işlevlerine karşılık masalların kimi olumsuzluklar taşıdığı da bilinmektedir. Kolta (1974)'ya göre bunların başında, çocuğun bilinçaltında korkuların yerleşmesine neden olan, masallardaki usdışı, korku verici yaratıkların ve şiddet öğelerinin yer alması gelir (Akt. Dilidüzgün, 2007). Aslan (2017: 133)'a göre "masalların bazılarının düş ürünü konu ve olaylar içermesi, çocukları yaşam gerçeklerinden uzaklaştırması, edilginleştirmesi, yanlış inançlara süreklemesi, doğru ve mantıkı düşünme alışkanlığının gelişmesini engellemesi, şiddet ve korkutucu öğeler ile cinsellik içeren konular içermesi gibi nedenlerle çocuklar için uygun değildir ve yine aynı nedenlerle kimi eğitimci, düşünür ve edebiyatçılar (Boileau, Rousseau...) da masal türünü çocuklar için tehlikeli bulmuşlardır." Bu açıdan çocukların masal türüyle etkileşime girmesini sağlayacak kişilerin (ebeveynler-eğitimciler) anılan sakıncaları dikkate almaları gerekmektedir.

Dünyanın içinden geçtiği bu çalkantılı dönemde değerlerde yaşanan çözülmeler yalnızca iyi olanaklara sahip olmanın yeterli olmadığı, çocukların erken yaşlarda özgün masal metinlerine yönlendirilmesi ve onları okumaya teşvik edilmesi gerektiği gerçeğini ortaya çıkarmıştır. Alanyazında değerler eğitimi ile ilgili çalışmaların ağırlık merkezini Türkçe ders kitaplarındaki değer/ler araştırmalarının oluşturduğu belirlenebilir (Karagöz, 2009; Akyol, 2010; Demir, 2012; Mert, 2013; Susar Kırmızı, 2014; Aytekin, 2015; Şahin, 2015). Buna karşılık alanyazında masal kitabı-değerler eğitimi ilişkisini inceleyen çalışma sayısının sınırlı olduğu görülmektedir. Bu kapsamda "Keloğlan Masalları" (Akkaya, 2014a); "Zaman Zaman İçinde" (Sever, Memiş ve Sever, 2015); "44 Türk Peri Masalı" (Kılcan, 2016) ile "Kelile ve Dimne" (Aktaş ve Beldağ, 2017); "Al'ı ile Fırfırı" (Akkaya, 2017b) adlı kitapların değerler eğitimi ekseninde incelenmiştir. Alanyazında Naki Tezel'in Türk Masalları adlı eserinin değerler eğitimi bakımından incelenmesine yönelik herhangi bir araştırmaya rastlanmamıştır. 
Bu araştırmaya Türk Masalları adlı eserdeki değerleri Schwartz Değer Ölçeği'ne göre sınıflandırmak ve eserin değerler eğitimi sürecindeki önemi belirlenmek istendiği için gereksinim duyulmuştur. Araştırma sonucunda eserin hangi değerleri içerdiğini belirleyerek duygu ve düşünce boyutunda eğitimli, ulusal değerleri özümsemiş kuşaklar yetiştirme amacına katkı sunulacağı düşünülmektedir.

Masallar çarpıcılık, yoğunluk ve uzun yaşam deneyimlerinin içinden süzülerek gelmiş olma nedeniyle eğitici bir boyut taşır (Özdemir, 2017). Bir ulusun değerler dünyasını tanımak o ulusun özgün masal metinlerini incelemeyi gerektirir. Bundan dolayı eğitimde özgün masal metinlerinin eğitsel yönünü kullanmak oldukça anlamlıdır. Araştırma, Türk Masalları adlı eser Türkçe eğitimi alanında yararlanılabilecek kaynak bir metin olduğundan ve ulaşılan bulguların değerler eğitimine katkı sağlayacağı düşünüldüğünden önemli görülmektedir.

Bu bağlamda araştırmanın soru cümlesi "Naki Tezel'in Türk Masalları adlı kitabındaki değer grupları nelerdir ve bunların sayısal dağılımları nedir?" olarak belirlenmiştir.

\section{Yöntem}

Bu çalışma nitel araştırma geleneğine dayalı bir doküman analizi çalışmasıdır. Nitel araştırma, gözlem, görüşme ve doküman analizi gibi nitel veri toplama yöntemlerinin kullanıldığı, algıların ve olayların doğal ortamda gerçekçi ve bütüncül bir biçimde ortaya konmasına yönelik nitel bir sürecin izlendiği araştırma olarak tanımlanabilir. Doküman incelemesi, araştııılması hedeflenen olgu veya olgular hakkında bilgi içeren yazılı materyallerin analizini kapsar (Yıldırım ve Şimşek, 2011).

Bu çalışmanın verileri Naki Tezel'in Türk Masalları adl kitabında yer alan toplam 54 masaldan toplanmıştır. Eserdeki masalların adları ve sayfa numaraları aşağıda gösterilmektedir:
1. Kırk Kardeş (s.23-44)
2. Peri KIzI (s.45-53)
3. Kısmetimi Arıyorum (s.54-73)
4. Peynir Tulumu (s.74-82)
5. Kara Kedi (s.83-99)
6. Keçi Kız (s.100-108)
7. Avcıoğlu (s.109-114)
8. Kırkıncı Oda (s.115-141)
9. Etme Bulma (s.142-148)
10. Bir Göze Bir Gül (s.149-155)
11. Altın Bülbül (s.156-186)
12. Yeşil Kuş (s.187-193)
13. Bahtiyar'la Hoptiyar (s.194-215)
14. Kırk Arap (s.216-222)
15. Ağlayan Nar ile Gülen Ayva (s.223-229)
16. Altmış Akıllı Yetmiş Fikirli (s. 230-233)
17. Ihtiyar Kuş (s.234-240) 
18. Sihirli Yüzük (s.241-248)

19. Altın Kozalaklı Gümüş Servi (s.249-253)

20. Seksen Göz (s.254-271)

21. Çifte Kambur (s.272-277)

22. Zanni Oğulları (s.278-282)

23. Kırk Oğlan (s.283-288)

24. Ala Balık (s.289-292)

25. Güneş KIzı (s. 293-309)

26. Kaldı ile Geldi (s. 310-314)

27. Altın Araba (s. 315-320)

28. Rüzgaroğlu (s. 321-330)

29. Fatma Nine (s. 331-335)

30. Mor Menekşe (s. 336-339)

31. Sihirli Tavşan (s.340-355)

32. Konuşan Kaval (s. 356-361)

33. Limon KIz (s. 362-373)

34. Akıllı Evlat (s. 374-378)

35. ibiş ile Memiş (s. 379-382)

36. Şamdan Kız (s. 383-392)

37. Tuz (s. 393-397)

38. Çoban Ali (s. 398-415)

39. Gururlu KIz (s. 416-420)

40. Kırk Haramiler (s. 421-435)

41. Sihirli Çeşme (s. 436-441)

42. Doğruluk (s.442-454)

43. Keloğlan ile ihtiyar (s.455-465)

44. Keloğlan Yemede (s.466-468)

45. Keloğlan'ın Ali Cengiz Oyunu (s.469-475)

46. Oduncu Keloğlan (s.476-478)

47. Keloğlan Hindistan Yolunda (s.479-487)

48. Keloğlan'ın Köseye Masalı (s.488-491)

49. Keloğlan Ölüyü Diriltiyor (s.492-500)

50. Tenbel Keloğlan (s. 501-503)

51. Dev ile Keloğlan (s.504-508)

52. Keloğlan Yedi Kat Yerin Altında (s.509-516)

53. Keloğlan'ın Tokmağı (s. 517-521)

54. Hamamcı ile Keloğlan (s. 522-527)

\section{Verilerin Analizi}

Verilerin çözümlenmesinde betimsel analiz yaklaşımı kullanılmıştır. Bu yaklaşıma göre, elde edilen veriler, daha önceden belirlenen temalara göre özetlenir ve yorumlanır. Bu tür analizde amaç, elde edilen bulguları düzenlenmiş ve yorumlanmış bir biçimde okuyucuya sunmaktır. Bu amaçla elde edilen veriler, önce sistematik bir biçimde betimlenir. Daha sonra yapılan bu betimlemeler açıklanır ve yorumlanır, neden-sonuç ilişkileri irdelenir ve birtakım sonuçlara ulaşılır (Yıldırım ve Şimşek, 2011: 239-240). 
Tablo 1.Schwartz'a göre değerlerin sınıflaması

\begin{tabular}{|c|c|}
\hline Değer tipi tanımları & Değer türleri için öğeler \\
\hline $\begin{array}{l}\text { Güç(power):Toplumsal konum, insanlar ve } \\
\text { kaynaklar üzerinde denetim gücü }\end{array}$ & $\begin{array}{l}\text { Sosyal güç sahibi olmak, otorite sahibi olmak, } \\
\text { zengin olmak, toplumdaki görüntüyü } \\
\text { koruyabilmek, insanlar tarafından benimsenmek. }\end{array}$ \\
\hline $\begin{array}{l}\text { Başarı(achievement):Toplumsalstandartlarıtemel } \\
\text { alan kişisel başarı yönelimi }\end{array}$ & $\begin{array}{l}\text { Başarılı olmak, yetkin, muktedir olmak, hırslı } \\
\text { olmak, sözü geçen biri olmak, zeki olmak. }\end{array}$ \\
\hline $\begin{array}{l}\text { Hazcılık(hedonism):Bireysel zevke ve hazza } \\
\text { yönelim }\end{array}$ & Zevk ve hayattan tat almak. \\
\hline Uyarılım(stimulation): Heyecan ve yenilik arayışı & $\begin{array}{l}\text { Cesur olmak, değişken bir hayat yaşamak, } \\
\text { heyecanlı bir yaşantı sahibi olmak. }\end{array}$ \\
\hline $\begin{array}{l}\text { Özyönelim(self-direction):Düşünce ve eylemde } \\
\text { bağımsızlık }\end{array}$ & $\begin{array}{l}\text { Yaratıcı olmak, merak duyabilmek, özgür olmak, } \\
\text { kendi amaçlarını seçebilmek, bağımsı olmak, } \\
\text { kendine saygısı olmak. }\end{array}$ \\
\hline $\begin{array}{l}\text { Evrenselcilik (universalism): Anlayışlılık, hoşgörü } \\
\text { ve tüm insanların ve doğanın iyiliğini gözetmek }\end{array}$ & $\begin{array}{l}\text { Açık fikirli olmak, erdemli olmak, toplumsal } \\
\text { adalet, eşitlik, dünyaya barış istemek, } \\
\text { güzelliklerle dolu bir dünya, doğayla bütünlük } \\
\text { içinde olma, çevreyi koruma, iç uyum. }\end{array}$ \\
\hline $\begin{array}{l}\text { İyilikseverlik (benevolence):Kişinin yakın olduğu } \\
\text { kişilerin iyiliğini gözetme ve geliştirme }\end{array}$ & $\begin{array}{l}\text { Yardımsever olmak, dürüst olmak, bağışlayıcı } \\
\text { olmak, sadık olmak, sorumluluk sahibi olmak, } \\
\text { gerçek arkadaşlık, olgun sevgi, manevi bir hayat, } \\
\text { anlamlı bir hayat, alçak gönüllü olmak. }\end{array}$ \\
\hline $\begin{array}{l}\text { Geleneksellik(tradition): Kültür ya da dinsel töre } \\
\text { ve fikirlere saygı ve bağlılık }\end{array}$ & $\begin{array}{l}\text { Alçakgönüllü olmak, dindar olmak, hayatın bana } \\
\text { verdiklerini kabullenmek, geleneklere saygılı } \\
\text { olmak, ılımlı bir hayat. }\end{array}$ \\
\hline $\begin{array}{l}\text { Uyma(confirm): Başkalarına zararverebilecek ve } \\
\text { toplumsalbeklentilere aykırı olabilecek dürtüve } \\
\text { eylemlerin sınırlanması }\end{array}$ & $\begin{array}{l}\text { Kibarlık, itaatkar olmak, anne babaya ve yaşlılara } \\
\text { değer vermek, kendini denetleyebilmek. }\end{array}$ \\
\hline $\begin{array}{l}\text { Güvenlik(security):Toplumun varolan ilişkilerin ve } \\
\text { kişinin kendisinin huzuru ve sürekliliği }\end{array}$ & $\begin{array}{l}\text { Ulusal güvenlik, toplumsal düzenin sürmesini } \\
\text { istemek. Temiz olmak, aile güvenliği, iyiliğe } \\
\text { karşılık vermek, bağlılık duygusu, sağlıklı olmak. }\end{array}$ \\
\hline
\end{tabular}

(Kuşdil ve Kağıtçıbaşı, 2000)

\section{işlem}

Araştırmada Karaman-Kepenekçi ve Aslan'ın (2013) çalışmalarında benimsediği yaklaşım tercih edilmiştir. Araştırmada bağlam birimi olarak "sözcük" ve "cümle" seçilmiş, değer ifadelerinin her bir cümlede ne sıklıkla geçtiği saptanmıştır. Sayma işlemi yapılırken hem açık içerik hem de gizli içerik göz önünde bulundurulmuştur. Bağlam birimi olarak seçilen her bir cümle içindeki değer gruplarına karşılık gelen sözcükler, belirtilen değer gruplarını açıklayan anlatımlar ya da doğrudan anlamı veren cümleler sayılmıştır.

Araştırmanın veri kaynağını oluşturan Türk Masalları kitabı araştırmacı tarafından birkaç kez okunmuştur. Okuma işleminden sonra veriler ayrıntılı biçimde formlara işlenmiştir. Ulaşılan verilerin değer gruplarındaki değer ifadelerine uygunluğuyla ile ilgili üç uzmandan görüş alınmıştır. Uzmanlardan gelen dönüşler çerçevesinde gerekli ekleme ve çıkarmalar yapılarak verilere şekil verilmiştir. Değer ifadeleriyle ilgili en doğru yargılara ulaşabilmek için 
alıntılar ve bağlamla ilgili bölümler tekrar tekrar okunmuştur. Veri kaybı yaşanmaması için de sayfa numaralarının doğruluğu kontrol edilmiştir.

Eserdeki her masal ayrıntılı biçimde okunduktan sonra veriler gruplandırılarak en net değer ifadeleri ilgili grubun altına işlenmiştir. Veriler sınıflandırılırken değer gruplarının altında kodlanan cümlelerden doğrudan alıntı için kullanılacak olanlar saptanmıştır. Bu aşamanın ardından veriler açık biçimde tanımlanarak alıntılarla desteklenmiştir.

Araştırmada daha sonra ulaşılan bulgular tanımlanmış, açıklanmış ve bulgulara anlam kazandırılmaya çalışılmıştır.

Bu bölüm yazıldıktan sonra araştırmanın inandırıcılığını sağlamak için bazı önlemler alınmıştır. Kitabın çözümlenmesi aşamasında araştırmacının varsayımlarından doğabilecek yanılgıları en aza indirgemek, değer gruplarıla ilgili içerikleri net olarak belirlemek ve hatalı değerlerdirmelere düşmemek amacıyla, çözümlenmiş veriler ile ilgili üç Türkçe eğitimi uzmanından teyid alınmıştır. Ayrıca, dikkat faktörü göz önünde tutularak değer gruplarıyla ilgili ifadeler sık sık gözden geçirilerek doğru biçimde kodlanmaya, araştırma sorusu çerçevesinde çözümlenmeye çalışılmıştır.

Nitel araştırmalarda kategorileri görsel olarak vermek geçerliği artırıp bulguları bütüncül biçimde görneyi sağlayacağından bazı bulgular tablo ve grafik hâlinde sunulmuştur.

\section{Bulgular}

Çalışmanın bu bölümünde araştırma sorusuna ilişkin bulgular, tablolar ve örnek alıntılar sunulmuştur.

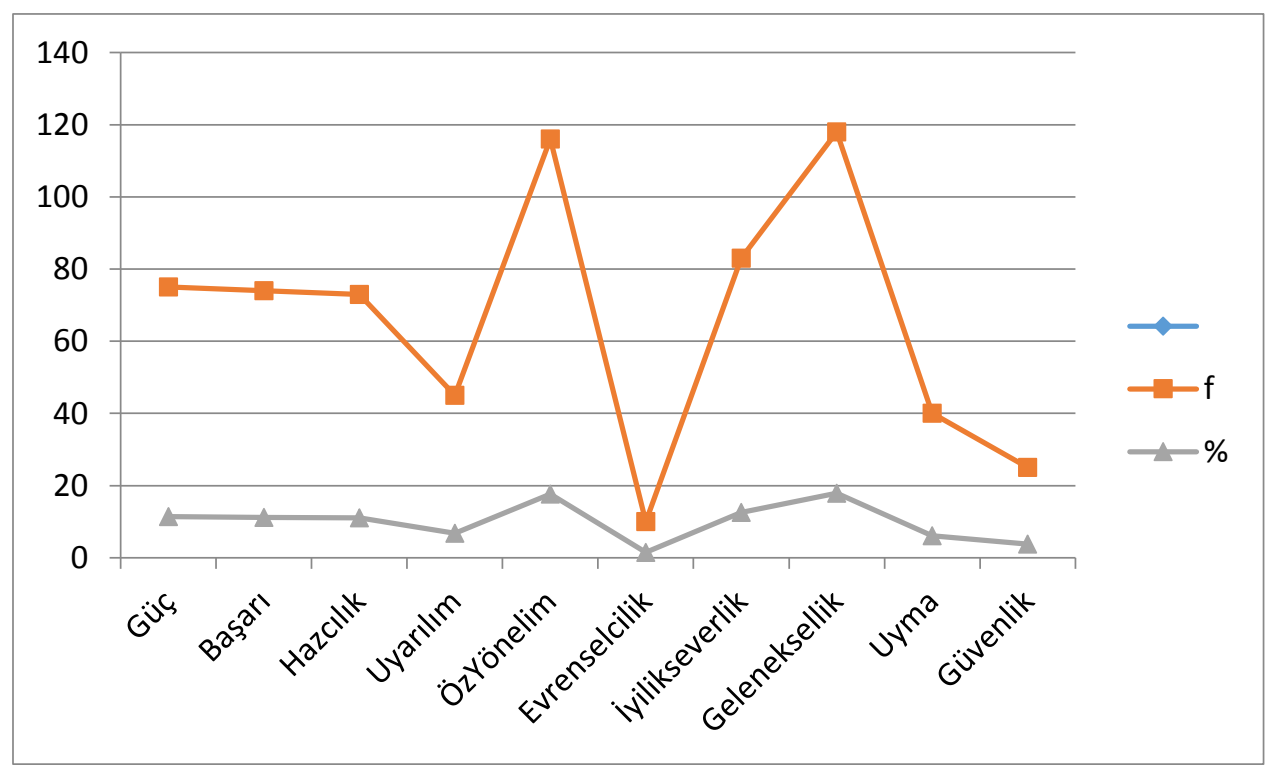

Grafik 1.Schwartz değer tiplerinin masallarda geçme sıklığı ve yüzde oranları 
Grafik 1, Türk Masalları adlı eserde yer alan değer gruplarının sıklığı ve yüzde oranlarını yansıtmaktadır. Grafikteki veriler incelendiğinde Türk Masalları kitabında yer alan değer grupları rastlanma sayısına göre ilk sırada \%17.90 ile geleneksellik(118) değer grubu yer almaktadır. Diğer değer grupları \%17.60 ile özyönelim(116), \%12.59 ile iyilikseverlik(83), \%11.38 ile güç(75), \%11.22 ile başarı(74), \%11.07 ile hazcılık(73), \%6.82 ile uyarılım(45), \%6.06 ile uyma(40), \%3.79 ile güvenlik(25) ve \%1.51 ile evrenselcilik(10) biçiminde sıralanmaktadır. Bu örüntü eserde geleneksellik, özyönelim, iyilikseverlik değeri içeren bulguların daha sık olduğuna işaret ederken evrenselcilik, güvenlik, uyma, uyarılım değer grupları ile ilgili ifadelerin daha az yer aldığını göstermektedir.

Tablo 2.Türk Masalları adlı kitapta Schwartz değer tiplerinin masallara göre dağılımı

\begin{tabular}{|c|c|c|c|c|c|c|c|c|c|c|c|c|}
\hline & Masallar & 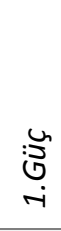 & $\begin{array}{l}\bar{\vdots} \\
\bar{g} \\
\delta \\
\infty \\
i\end{array}$ & 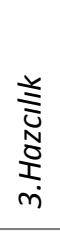 & 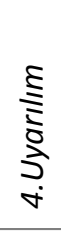 & 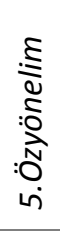 & 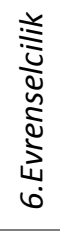 & 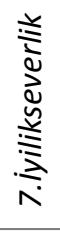 & 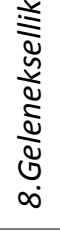 & 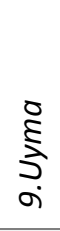 & 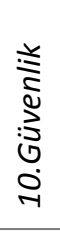 & $\frac{5}{\frac{5}{2}}$ \\
\hline 1 & Kırk Kardeş & 11 & 8 & 7 & 9 & 11 & - & 9 & 16 & 5 & 3 & 79 \\
\hline 2 & Peri Kızı & - & - & - & 1 & 6 & - & 2 & 3 & - & - & 12 \\
\hline 3 & $\begin{array}{l}\text { Kısmetimi } \\
\text { Arıyorum }\end{array}$ & 7 & 1 & 4 & 5 & 7 & 1 & 3 & 10 & 1 & 4 & 43 \\
\hline 4 & Peynir Tulumu & - & 3 & 6 & 1 & 6 & - & 1 & 8 & 2 & - & 27 \\
\hline 5 & Kara Kedi & 2 & - & 1 & - & 7 & - & 1 & 5 & - & 2 & 18 \\
\hline 6 & Keçi Kız & 2 & 1 & 6 & - & 3 & - & 4 & 3 & 1 & - & 20 \\
\hline 7 & Avcıoğlu & 3 & 6 & 3 & 3 & 3 & - & - & 2 & - & - & 20 \\
\hline 8 & Kırkıncı Oda & 2 & 3 & 2 & 4 & 7 & 2 & 6 & - & 2 & 1 & 29 \\
\hline 9 & Etme Bulma & 2 & - & 2 & - & - & - & - & 1 & - & - & 5 \\
\hline 10 & $\begin{array}{l}\text { Bir Göze Bir } \\
\text { Gül }\end{array}$ & - & 1 & 3 & - & - & 1 & 1 & - & 2 & - & 8 \\
\hline 11 & Altın Bülbül & 4 & 4 & 2 & 6 & 4 & - & 6 & 11 & 5 & 1 & 43 \\
\hline 12 & Yeşil Kuş & - & - & 1 & - & - & - & 1 & 2 & 1 & - & 5 \\
\hline 13 & $\begin{array}{l}\text { Bahtiyar'la } \\
\text { Hoptiyar }\end{array}$ & 3 & 1 & 1 & 1 & 4 & - & 1 & 3 & - & - & 14 \\
\hline 14 & Kırk Arap & - & - & 2 & 1 & 3 & - & - & 1 & - & - & 7 \\
\hline 15 & $\begin{array}{l}\text { Ağlayan Nar } \\
\text { İle Gülen Ayva }\end{array}$ & - & 2 & 2 & - & - & - & 2 & 2 & - & - & 8 \\
\hline 16 & $\begin{array}{l}\text { Altmış Akıllı } \\
\text { Yetmiş Fikirli }\end{array}$ & - & - & 1 & 1 & 2 & - & - & 1 & - & - & 5 \\
\hline 17 & İhtiyar Kuş & - & 1 & - & 1 & - & - & 2 & 2 & 1 & - & 7 \\
\hline 18 & Sihirli Yüzük & - & - & - & - & - & 2 & 2 & 3 & - & - & 7 \\
\hline 19 & $\begin{array}{l}\text { Altın Kozalaklı } \\
\text { Gümüş Servi }\end{array}$ & - & - & - & - & 1 & - & - & 2 & 1 & - & 4 \\
\hline 20 & Seksen Göz & 1 & 1 & - & - & 2 & - & 4 & - & - & - & 8 \\
\hline 21 & Çifte Kambur & - & - & 4 & - & - & - & 1 & - & - & - & 5 \\
\hline 22 & Zanni Oğulları & 2 & 1 & - & - & 2 & - & - & - & - & 2 & 7 \\
\hline 23 & Kırk Oğlan & - & - & 1 & 2 & 2 & - & - & 1 & - & 1 & 7 \\
\hline 24 & Ala Balık & 1 & - & 1 & - & 2 & - & - & 1 & - & - & 5 \\
\hline
\end{tabular}




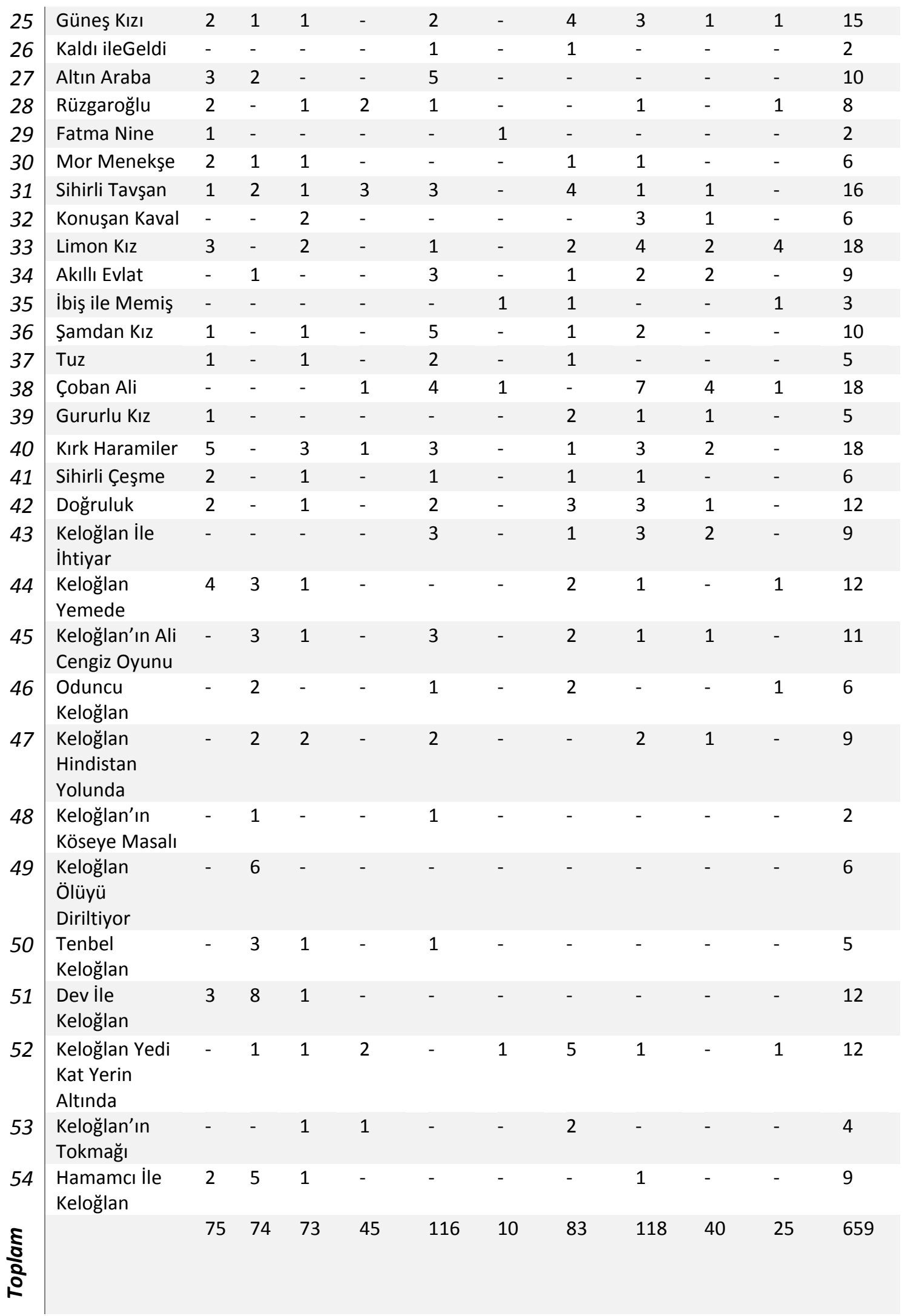

Tablo 2'deki bulgular incelendiğinde Kırk Kardeş(16), Altın Bülbül(11), Kısmetimi Arıyorum(10), Peynir Tulumu (8), Çoban Ali (7) adlı masallarda geleneksellik değer grubuna ilişkin değer ifadelerinin daha fazla yer aldığı görülmektedir. TablodaKırkıncı Oda, Bir Göze 
Bir Gül, Seksen Göz, ÇifteKambur, Zanni Oğulları, Kaldı ile Geldi, Altın Araba, Fatma Nine, ỉbiş ile Memiş, Tuz, Oduncu Keloğlan, Keloğlan’ın Köseye Masalı, Keloğlan Ölüyü Diriltiyor, Tenbel Keloğlan, Dev İle Keloğlan, Keloğlan'ın Tokmağı adını taşıyan masallarda geleneksellik değer grubuna ilişkin herhangi bir bulgunun olmadığı görülmüştür. Aşağıda Türk Masalları adlı eserde geleneksellik değer grubuna ilişkin bazı alıntılar sunulmuştur:

["Kırk gün, kırk gece süren bir dügünden sonra peri kızı ile oğlan evlenmişler"] (s.47/30-31)

["Size damat olmak benim için büyük bir şereftir padişahım, demiş, ama, arkadaşım Alev benden büyüktür. Evlenme sırası ondadır."] (s.63/15-17)

["Güzel bir dügün yapmışlar. Padişah ile Ayşe evlenmiş"] (s.147/5)

["Eh, ne yapalım, diye cevap vermiş, bana da bataklık yol kalıyor. Ben kısmetime razıyım. Haydi hoşça kalın"] (s.158/20-21)

["Sonra küçük oğlan Hızır Dede'nin elini öpmüş"] (s.174/30-31)

Tablo 2'deki bulgular incelendiğinde Kırk Kardeş (11), Kara Kedi (7), Kısmetimi Arıyorum (7), Kırkıncı Oda (7), Peri Kızı (6), Peynir Tulumu (6), Altın Araba (5), Şamdan Kız (5) adlı masallarda özyönelim değer grubuna ilişkin değer ifadelerinin daha fazla yer aldığı görülmektedir. Etme Bulma, Bir Göze Bir Gül, Yeşil Kuş, Ağlayan Nar İle Gülen Ayva, ìhtiyar Kuş, Sihirli Yüzük, ÇifteKambur, Fatma Nine, Mor Menekşe, Konuşan Kaval, ỉbiş ile Memiş, Gururlu Kız, Keloğlan Yemede, Keloğlan Ölüyü Diriltiyor, Dev Ile Keloğlan, Keloğlan Yedi Kat Yerin Altında, Keloğlan'ın Tokmağı, Hamamcı Ille Keloğlan adını taşıyan masallarda özyönelim değer grubuna ilişkin bir bulguya rastlanılmamıştır. Aşağıda Türk Masalları adlı eserde özyönelim değer grubuna ilişkin bazı alıntılar sunulmuştur:

["Ben bu ağlardan birine tutunup dünyaya çıkacağım, demiş, Haydi hoşça kalın!] (s.47/20-21)

["Kulübede bir zaman oturduktan sonra gözüne bir kapı ilişmiş. Kalkıp açmış"] (s.87/30-31)

["Yemen padişahının memleketimden birçok atılar çıktı da nereye gidecekler diye anlamak için dinliyorum..."] (s.112/23-24)

["Dur bakayım, demiş, bu horoz suyu nereye götürüyor?...Testiyi yere bırakarak horozun peşine takılmış."] (s.199/11-12)

Tablo 2' deki bulgular göz önünde bulundurulduğunda Kırk Kardeş (9), Kırkıncı Oda (6), Altın Bülbül (6), Keloğlan Yedi Kat Yerin Altında (5) adlı masallarda iyilikseverlik değer grubuna ilişkin değer ifadelerinin daha fazla yer aldığı görülmektedir. Avcıoğlu, Etme Bulma, Kırk Arap, Altmış Akıllı Yetmiş Fikirli, Altın Kozalaklı Gümüş Servi, Zanni Oğulları, Kırk Oğlan, 
Ala Balık, Altın Araba, Rüzgaroğlu, Fatma Nine, Konuşan Kaval, Çoban Ali, Keloğlan Hindistan Yolunda, Keloğlan'ın Köseye Masalı, Keloğlan Ölüyü Diriltiyor, Tenbel Keloğlan, Dev İle Keloğlan, Hamamcı ile Keloğlan başıklı masallarda iyilikseverlik değer grubuna ilişkin herhangi bir bulgu saptanamamıştır. Aşağıda Türk Masalları adlı eserde iyilikseverlik değer grubuna ilişkin bazı alıntılar sunulmuştur:

["Yalan söylemek âdetim değildir anne. Bunu sen de bilirsin. Evet, gördügüm şey hakikaten süttü."] (s.45/22-23)

["Ne olur anneciğim, demiş, aşçıbaşıya ben de yardım edeyim..."] (s.107/25)

["Ben sadece görevimi yaptım padişahım."] (s.140/33)

["Kaplan Adam, artık bir padişah vekili olduğu için memleketin bütün işlerine bakıyor her şeyi düşünmek zorunda kalıyormuş"] (s.120/5-6)

Tablo 2'deki bulgular incelendiğinde Kırk Kardeş (11), Kısmetimi Arıyorum (7), Kırk Haramiler (5) başlıklı masallarda güçdeğer grubuna ilişkin değer ifadelerinin daha yoğun olduğu belirlenmiştir. Peri Kızı, Peynir Tulumu, Bir Göze Bir Gül, Yeşil Kuş, Kırk Arap, Ağlayan Nar İle Gülen Ayva, Altmış Akıllı Yetmiş Fikirli, ìhtiyar Kuş, Sihirli Yüzük, Altın Kozalaklı Gümüş Servi, ÇifteKambur, Kırk Oğlan, Kaldı ile Geldi, Konuşan Kaval, Akıllı Evlat, İbiş ile Memiş, Çoban Ali, Keloğlan İle İhtiyar, Keloğlan'ın Ali Cengiz Oyunu, Oduncu Keloğlan, Keloğlan Hindistan Yolunda, Keloğlan'ın Köseye Masalı, Keloğlan Ölüyü Diriltiyor, Tenbel Keloğlan, Keloğlan Yedi Kat Yerin Altında, Keloğlan'ın Tokmağı başlıklı masallarda güç değer grubuna ilişkin bir bulgunun olmadığı görülmüştür. Aşağıda Türk Masalları adlı eserde yer alan güç değer grubuna ilişkin bazı alıntılar sunulmuştur:

["Ben bir padişah oğluyum, demiş, hiçbir şeye ihtiyacım yok..."]s.35/8-9

[..."Istediğim zaman, yerin altında ne olup bittiğini anlayabilirim."]s.60/12-13

["Filan gün bütün kızlar birer kap yemek yaparak saraya gelecekler,"diye tellal bağırtmış.]103/1-3

["Vurun bunun başını! Diye emretmiş, çıkıp gitmiş. "]s.148/7

Tablo 2'deki bulgular incelendiğinde Kırk Kardeş (8), Dev İle Keloğlan (8), Avcıoğlu (6), Keloğlan Ölüyü Diriltiyor (6), Hamamcı İle Keloğlan (5), adlı masallarda başarı değer grubuna ilişkin değer ifadelerinin daha sık yer aldığı görülmektedir. Peri Kızı, Kara Kedi, Etme Bulma, Yeşil Kuş, Kırk Arap, Ağlayan Nar Ille Gülen Ayva, Altmış Akıllı Yetmiş Fikirli, ihtiyar Kuş, Sihirli Yüzük, Altın Kozalaklı Gümüş Servi, ÇifteKambur, Kırk Oğlan, Kaldı ile Geldi, Konuşan Kaval, İbiş ile Memiş, Şamdan Kız, Tuz, Çoban Ali, Gururlu Kız, Kırk Haramiler, Limon Kız, 
Keloğlan'ın Tokmağı, Sihirli Çeşme, Doğruluk, Keloğlan İle îhtiyar adını taşıyan masallarda başarı değer grubuna ilişkin bir ifadenin olmadığı görülmüştür. Aşağıda Türk Masalları adlı eserde başarı değer grubuna ilişkin bazı alıntılar sunulmuştur:

[..."Istediğim gibi, hepsi de bir anadan, bir babadan olma kırk kız kardeş buldum."] (s.28/13-15)

["Sokakta hemen bastonuna atlamış. Kırkıncı günü akşamüzeri ejderhanın sarayına inmiş. Sihirli çalgıyı ejderhaya vererek nişanlısını kapalı olduğu yerden kurtarmıs.."] (s.44/4-6)

["Ertesi gün kocakarı, yirmi küp dolusu gümüşü arabalarla padişahın sarayına götürüp sultana vermiş."] (s.75/8-9)

["ihtiyar, işte senin ele geçmez dediğin arap avucumun içinde, demiş. Bak ne kuzu gibi, görüyor musun?!] (s.139/27-28)

Tablo 2'deki bulgular göz önünde bulundurulduğunda Kırk Kardeş(7), Peynir Tulumu(6), Keçi Kız(6) adlı masallarda hazcılık değer grubuna ait değer ifadelerinin daha sık kullanıldığı görülmektedir. Peri Kızı, İhtiyar Kuş, Sihirli Yüzük, Altın Kozalaklı Gümüş Servi, Seksen Göz,, Zanni Oğulları, Kaldı ile Geldi, Altın Araba, Fatma Nine, Akıllı Evlat, İbiş ile Memiş, Çoban Ali, Gururlu Kız, Keloğlan İle İhtiyar, Oduncu Keloğlan, Keloğlan'ın Köseye Masalı, Keloğlan Ölüyü Diriltiyor başlıklı masallarda hazcılık değer grubuna ilişkin herhangi bir bulgunun olmadığı görülmüştür. Aşağıda Türk Masalları adlı eserde hazcılık değer grubuna ilişkin bazı alıntılar sunulmuştur:

[“Padişah, kırk gün, kırk gece dügün yaparak, küçük oğlunu da evlendirmiş."] (s.44/30-31)

["Peynir tulumu, katıla katıla gülmeye, oda içinde zıp zıp sıçramaya başlamış."] (s.76/5-6)

["Artık, demiş, bizim için düşman tehlikesi kalmadı. Son günlerde çok da yoruldum. Mısır ülkesine kadar gidip bir gezinti yapmak, Mısır padişahına birkaç ay misafir olmak istiyorum."] (s.119/21-23)

["O sıralarda padişah da ormanda ava çıkmış."] (s.154/25)

Tablo 2'deki bulgular incelendiğinde Kırk Kardeş(9), Altın Bülbül(6), Kısmetimi Arıyorum(5) adlı masallarda uyarılım değer grubuna ait değer ifadelerinin daha çok kullanıldığı görülmektedir. Kara Kedi, KeçiKız, Etme Bulma, Bir Göze Bir Gül, Yeşil Kuş, Ağlayan Nar ile Gülen Ayva, Sihirli Yüzük, Altın Kozalaklı Gümüş Servi, Seksen Göz, ÇifteKambur, Zanni Oğulları, Ala Balık, Güneş Kızı, Kaldı ile Geldi, Altın Araba, Fatma Nine, Mor Menekşe, Konuşan Kaval, Limon Kız, Akıllı Evlat, ibiş ile Memiş, Şamdan Kız, Tuz, Gururlu Kız, Keloğlan Yemede, Keloğlan Ölüyü Diriltiyor, Dev Ille Keloğlan, Keloğlan Yedi Kat Yerin 
Altında, Keloğlan'ın Tokmağı, Hamamcı ille Keloğlan başlıklı masallarda uyarılım değer grubu ile ilgili herhangi bir ifadenin olmadığı görülmüştür. Aşağıda Türk Masalları adlı eserde uyarılım değer grubuna ilişkin bazı alıntılar sunulmuştur:

["Ay ışığında gördügü şey o kadar korkunç, o kadar korkunçmuş ki, gene de cesaretini kaybetmemiş."] (s.31/22-23)

["Acar ile Alev, "Böyle oturacağımıza, gidip savaşı seyredelim," diyerek saraydan çıkmışlar. Atlarına atlayıp dörtnala sürerek savaş meydanına gitmişler. Bir de ne görsünler? Düşman askerleri pek fazla, padişahın askerleri ise pek az. Savaş çok çetin. Padişahın askerleri durmadan geri çekiliyor, yeniliyorlar... Acar dayanamamış. Arkadaşına..."Sen burada kal Alev, demiş, ben savaşa gidiyorum!" Sözünü daha bitirmeden, atını sürüp savaş meydanına atılmış.] (s.61/1-9)

["içinde birdenbire bir sevinç parlamış. Düşman elindeki bir tutsağın yerini bulmuş ve onu kurtarmış gibi heyecanlanmış."] (s.131/12-13)

["Çabuk hazırlanın, diye emir vermiş, derhal o padişahın memleketine gideceğiz. Şehzade Altın Bülbül'ü nasıl kaçırdığını doğru anlatırsa, neâlâ... Yok, yalan söylerse, o memleketi yakıp yıkacağız. Sarayı padişahın da, oğlunun da başına geçireceğiz."] (s.181/23-27)

Tablo 2'deki bulgular göz önünde bulundurulduğunda Kırk Kardeş (5), Altın Bülbül(5), Çoban Ali (4) adlı masallarda uyma değer grubuna ait değer ifadelerinin daha fazla kullanıldığı görülmektedir. Peri Kızı, Peynir Tulumu, Avcıoğlu, Etme Bulma, Bahtiyar'la Hoptiyar, Kırk Arap, Ağlayan Nar Ile Gülen Ayva, Altmış Akıllı Yetmiş Fikirli, Sihirli Yüzük, Seksen Göz, ÇifteKambur, Zanni Oğulları, Kırk Oğlan, Ala Balık, Kaldı ile Geldi, Altın Araba, Rüzgaroğlu, Fatma Nine, Mor Menekşe, İbiş ile Memiş, Şamdan Kız, Tuz, Sihirli Çeşme, Keloğlan Yemede, Oduncu Keloğlan, Keloğlan'ın Köseye Masalı, Keloğlan Ölüyü Diriltiyor, Tenbel Keloğlan, Dev Ille Keloğlan, Keloğlan Yedi Kat Yerin Altında, Keloğlan'ın Tokmağı, Hamamcı Ille Keloğlan başlıklı masallarda uyma değer grubu ile ilgili herhangi bir ifade saptanamamıştır. Aşağıda Türk Masalları adlı eserde uyma değer grubuna ilişkin bazı alıntılar sunulmuştur:

["Şehzadeler hemen yerlerinden kalkıp önce babalarının, sonra da annelerinin ellerini öperek odadan çıkmışlar."] (s.28/20-21)

["O senin karınsa, benim de gelinimdir. Dişim etime, etim dişime geçsin ki hiçbir şey yapmam."] (s.82/2-3)

["Hatasını anlamış. Bir daha da haksızlık yapmamaya karar vermiş"] (s.193/22-23) 
Tablo 2'deki bulgular incelendiğinde Kısmetimi Arıyorum (4), Limon Kız (4) adlı masallarda güvenlik değer grubuna ait değer ifadelerinin daha yoğun biçimde kullanıldığı görülmektedir. Peri Kızı, Peynir Tulumu, Keloğlan'ın Tokmağı, Hamamcı Ile Keloğlan, Etme Bulma, Bir Göze Bir Gül, Yeşil Kuş, Bahtiyar'la Hoptiyar, Kırk Arap, Ağlayan Nar İle Gülen Ayva, Altmış Akıllı Yetmiş Fikirli, îhtiyar Kuş, Sihirli Yüzük, Altın Kozalaklı Gümüş Servi, Seksen Göz, ÇifteKambur, Ala Balık, Kaldı ile Geldi, Altın Araba, Fatma Nine, Mor Menekşe, Sihirli Tavşan, Konuşan Kaval, Akıllı Evlat, Şamdan Kız, Tuz, Gururlu Kız, Kırk Haramiler, Sihirli Çeşme, Doğruluk, Keloğlan ille intiyar, Keloğlan'ın Ali Cengiz Oyunu, Keloğlan Hindistan Yolunda, Keloğlan'ın Köseye Masalı, Keloğlan Ölüyü Diriltiyor, Tenbel Keloğlan, Dev Iile Keloğlan, Keçi Kız, Avcıoğlu başıklı masallarda güvenlik değer grubu ile ilgili bir bulgunun olmadığı görülmüştür. Aşağıda Türk Masalları adlı eserde güvenlik değer grubuna ilişkin bazı alıntılar sunulmuştur:

[“Oğlum, demiş, sen benim karıncalarıma çok büyük iyilik yaptın! Dile benden ne dilersin?”]

["Sana iyi bir eş olmaya çalışacağım, demiş, hayatımı kurtardığın için ölünceye kadar tek amacım seni mutlu etmektir."] (s.67/15-16)

["Biz onu tutmayız. Yedi yıldır birimize et, birimize de ot yediriyorsunuz. O bize yardım etti. Etle otun yerini değiştirdi. İiliğe karşılık kötülük yapamayız."] (s.169/18-20)

Tablo 2'deki bulgular göz önünde bulundurulduğunda Sihirli Yüzük(2), Kırkıncı Oda(2) adlı masallarda evrenselcilik değer grubuna ait değer ifadelerinin daha sık kullanıldığı görülmektedir. Kırk Kardeş, Peri Kızı, Peynir Tulumu, Kara Kedi, Keçi Kız, Avcıoğlu, Etme Bulma, Altın Bülbül, Yeşil Kuş, Bahtiyar'la Hoptiyar, Kırk Arap, Ağlayan Nar İle Gülen Ayva, Altmış Akıllı Yetmiş Fikirli, İhtiyar Kuş, Altın Kozalaklı Gümüş Servi, Seksen Göz, ÇifteKambur, Zanni Oğulları, Kırk Oğlan, Ala Balık, Güneş Kızı, Kaldı ile Geldi, Altın Araba, Rüzgaroğlu, Mor Menekşe, Sihirli Tavşan, Konuşan Kaval, Limon Kız, Akıllı Evlat, Şamdan Kız, Tuz, Gururlu Kız, Kırk Haramiler, Keloğlan'ın Tokmağı, Hamamcı Ille Keloğlan, Sihirli Çeşme, Doğruluk, Keloğlan Iile İhtiyar, Keloğlan Yemede, Keloğlan'ın Ali Cengiz Oyunu, Oduncu Keloğlan, Keloğlan Hindistan Yolunda, Keloğlan'ın Köseye Masalı, Keloğlan Ölüyü Diriltiyor, Tenbel Keloğlan, Dev İle Keloğlan başlıklı masallarda evrenselcilik değer grubu ile ilgili herhangi bir bulgunun olmadığı görülmüştür. Aşağıda Türk Masalları adlı eserde evrenselcilik değer grubuna ilişkin bazı alıntılar sunulmuştur:

["Neme lazım, demiş, insanın alın teriyle kazandığı kendi parası olmadıktan sonra, değeri mi olur...Sağlık her şeyden üstün. Insan çalışıp kazanmalı, öyle yemeli... Başkasının parasından bana ne?"] (s.121/15-18) 
["Eşime fenalık yapamam. Kendi evim saraydan daha iyi. Kocam da yiğit bir adam...] (s.247/16-17)

\section{Tartışma ve Sonuç}

Bu araştırmada, Naki Tezel'in Türk Masalları adlı kitabı Schwartz Değer Ölçeği'ne dayalı olarak değerler eğitimi açısından incelenmiştir. Araştırma kapsamında yapılan incelemelerden elde edilen bulgular genel olarak değerlendirildiğinde eserde geleneksellik ve özyönelim değer gruplarının ön plana çıktığı; evrenselcilik değer grubunun yeterli ölçüde yer almadığı belirlenmiştir.

Çalışma sonucunda Türk Masalları kitabında karşılaşılan değer grupları rastlanma sayısına göre büyükten küçüğe doğru geleneksellik(118), özyönelim(116), iyilikseverlik(83), güç(75), başarı(74), hazcılık(73), uyarıım(45), uyma(40), güvenlik(25), evrenselcilik(10) biçiminde sıralanmıştır. Çalışmanın bu bulgusu alanyazın verileriyle tutarlıdır. Akkaya (2014a),Sever, Memiş, Sever (2015) ile Aktaş ve Beldağ'ın (2017) çalışmalarında benzer bir sonuç elde edilmiştir. Anılan çalışmalarda da geleneksellik, özyönelim, güç ve başarı değer grubunun daha sık yer aldığı belirlenmiştir.

Eserde özyönelim değer grubunun alt bileşenlerinden olan yaratıcılık, merak, özgürlük, amaçııık, bağımsızlık, özsaygı ifadelerinin sıkça yer aldığı bulgulanmıştır. Yavuzer'e göre (2011: 144-115) çocukluğun son evresinde çocuklar merak ettikleri çeşitli becerileri kazanmaya başlar, düşündüklerini işlevsel düzeyde gerçekleştirir, kendiliğinin ayırdına varır, dış etkilerin uzağında problemlerini çözebilir, her işin en iyisini yapmak için çabalar. Bu duruma dayalı olarak kitaptaki iletilerin çocuğun gelişim evreleriyle uyumlu bir örüntü sunduğu söylenebilir.

Eserdeki masallarda evrenselcilik değer ifadelerinin sınırlı sayıda yer aldığı belirtilebilir. Alanyazın tarandığında önceki araştırmaların da benzer sonuçları işaret ettiği görülmektedir. Akkaya (2014a) ve Sever, Memiş, Sever (2015) yürüttüğü araştırmalarda evrenselcilik değer grubunun çok az yer aldığı sonucuna ulaşmışlardır. Bu sonuç yazınsal türler içinde masalın geleneksel yönünün güçlü olmasından kaynaklanıyor olabilir.

Aktaş ve Beldağ (2017) yürüttükleri araştırmada hazcllık değer grubundaki ifadelere çok az yer verildiğini bulgulamıştır. Buna karşın bu araştırmada hazcılıkla ilgili ifadelerin daha yoğun olduğu elde edilen bir diğer sonuçtur. Bu durum Türk kültürünü yansıtan derlenmiş masalların Doğu kültürünün özgün örneklerinden Kelile ve Dimne'den bakış açısı olarak farklı olduğunu gösterir niteliktedir. 
Akkaya (2017b) Schwartz Değer Ölçeği'ne dayalı olarak Oğuz Tansel'in masalları üzerine bir araştıma gerçekleştirmiştir. Araştırmacı, Tansel'in masallarında evrenselcilik değeri ile geleneksellik değerinin aynı düzeyde yer aldığı sonucuna varmıştır. Akkaya'nın (2017b) çalışması yöntem bakımından bu çalışmayla aynı, ortaya koyduğu sonuç açısından farklıdır.

Türk Masalları adlı eserde kediye işkence yaparak döven insanlar, insan yiyen korkunç devler, kızının gözünü çıkarmak isteyen üvey anne, kardeşlerini uçurumdan atmak isteyen ağabeyler, eşine her gün kırk sopa atan koca gibi korku ve şiddet içeren olumsuz örnekler yer almaktadır. Bir başka deyişle kimi masalların eğitsellik boyutu ile ilgili sorunlu iletiler taşıdığını söylemek mümkündür. Bu durumda yapılması gereken eğitimcilerin özenli davranarak, korku ve şiddet öğeleri barındıran masalları sınıf ortamında kullanmamalarıdır. Bu yaklaşım, Akkaya'nın (2014a) ve Kılcan'ın (2016) bakış açısıyla uyumludur. Her iki çalışma da masallarla ilgili okumalarda öğretmen ve velilerin özenli olmaları, çocuklara kötü örnek olabilecek masalları okuma listesinden çıkarmaları gerektiğini bildirmektedir.

Araştırmada ulaşılan sonuçlara göre getirilen öneriler öğretmenlere, ileride yapılacak araştırmalara ve ebeveynlere dönük olmak üzere aşağıda belirtilmiştir:

- Türkçe, değerler eğitiminin etkili ve kapsamlı bir şekilde gerçekleştirildiği temel derstir. Değerler eğitimi çerçevesinde engin kültürel birikimden beslenen, değerlerle donanmış sözlü kültür birikiminin öğrencilerle buluşturulması gereklidir. Bu konudaki duyarlılığın artması için söz konusu kitapla çocuklar arasında etkileşim kurulması yararlı olabilir.

- Türk Masalları adlı eserde bulunan değerler sayfa ve satır numarası tablo olarak ekte sunulduğu için derslerde kazandırılmak istenen değerlere göre seçilerek öğrencilere sunulabilir.

- Naki Tezel'in Türk Masalları adlı eseri değerler eğitimi açısından ilk defa bu çalışmada incelenmiştir. Yazarın diğer kitapları da bu kapsamda ele alınarak Türkçe dersleri değer kazandırıcı örnek dil ve kültür öğretimi ortamına dönüştürülebilir.

- Masallar günümüz ve gelecek için geçerli olan önemli iletiler barındırmaktadır. Bunların eğitim-kültür ortamlarında kullanılması, öğrenciler-öğretmenler tarafından dikkatle incelenmesi, özümsenmesi gelecek kuşakların ortak bir kültürel doku etrafında birleşmesini, ulusal değerler sistemiyle ilişki kurmasını sağlayabilir. 


\section{Kaynaklar}

Akkaya, N. (2014a). "Keloğlan masallarında yer alan değerlerin incelenmesi."Akademik Sosyal Araştırmalar Dergisi, 2(2), 312-324.

Akkaya, N. (2017b). Oğuz Tansel'in masal dünyasında değerler. S. Sever, S. Karagül (Yay. Haz.), Uluslararasi Türk Masal Dünyasi ve Doğumunun 100. Yilinda Oğuz Tansel Sempozyumu Bildiriler Kitabı (ss. 99-106).Ankara: Ankara Üniversitesi ÇOGEM.

Aktaş, E. ve Beldağ, A. (2017)."Kalila and Dimna as one of the traditional antecedents of modern classifications of values". International Education, 10 (3), 46-53.

Akyol, Ş. (2010). İlköğretim 6. sınıf Türkçe ders kitaplarında yer alan sevgi temasının değerler eğitimi açısından incelenmesi. Çanakkale: Çanakkale Onsekiz Mart Üniversitesi, Yayınlanmamış yüksek lisans tezi.

Arıcı, A. F. (2016). "Estetik değer oluşturmada masalların rolü: Türk masalları örneği."Erzincan Üniversitesi Eğitim Fakültesi Dergisi, 18(2), 1017-1035.

Aslan, C. (2017). Oğuz Tansel'in derleyip yazdığı masalların duyarlık eğitimi bağlamında incelenmesi. S. Sever, S. Karagül (Yay. Haz.), Uluslararasi Türk Masal Dünyasi ve Doğumunun 100. Yilinda Oğuz Tansel Sempozyumu Bildiriler Kitabı (ss. 131-152).Ankara: Ankara Üniversitesi ÇOGEM.

Aydın, M. (2003). "Gençliğin değer algısı: Konya örneği."Değerler Eğitimi Dergisi, 1 (3), 121-144.

Aytekin, M. (2015). Ortaokul Türkçe ders kitaplarının değer iletimi açısından incelenmesi. İzmir: Dokuz Eylül Üniversitesi, Yayınlanmamış yüksek lisans tezi.

Beldağ, A. (2012). İlköğretim yedinci sınıf sosyal bilgiler dersindeki değerlerin kazanılma düzeyinin çeşitli değişkenler açısından incelenmesi (Erzurum ili örneği). Erzurum: Atatürk Üniversitesi, Yayınlanmamış Doktora Tezi.

Bolay, S. H. (2007). Aşkın değerler buhranı, değerler ve eğitimi.R. Kaymakcan, S. Kenan, H. Hökelekli, Z. Ş. Arslan, M Zengin (Ed.),Değerler ve Eğitimi(ss. 55-69). İstanbul: Değerler Eğitimi Merkezi Yayınları.

Demir, T. (2012). "ilköğretim sekizinci sınıf Türkçe ders kitaplarındaki hikâye metinlerinde yer alan değer unsurlarının eşdizimsel örüntülemeler açısından görünümleri." Turkish Studies, 7 (2), 1063- 1078.

Dilidüzgün, S. (2007). Çağdaş Çocuk Yazını (2. Basım). İstanbul: Morpa Kültür Yayınları.

Ekşi, H. (2003). "Temel insani değerlerin kazandırılmasında bir yaklaşım: Karakter eğitimi programları."Değerler Eğitimi Dergisi, 1 (1), 79-96.

Elçin, Ş. (1993). Halk edebiyatına giriş. Ankara: Akçağ Yayınları.

Günay, U. (1992). Masal, Türk Dünyası El Kitabı. (C3, 326). Ankara: Türk Kültürünü Araştırma Enstitüsü Yayınları.

Güney, E. C. (1971). Folklor ve halk edebiyatı. İstanbul: Millî Eğitim Yayınları.

Güngör, E. (2010). Değerler psikoloji üzerinde araştırmalar (4. Basım). İstanbul: Ötüken Yayınları.

Hall, B. (2003). The Omega Factor: A values-based approach for developing organizations and leadership. Paper presented at 2003 Servant Leadership Forum: Serving Students and the Common Good. 29 Mayıs 2017'de www.georgiahumanities.org adresinden alınmıştır.

Halstead, J. M., \& Taylor, M. J. (2000)."Learning and teaching about values: A review of recent research."Cambridge Journal of Education, 30 (2), 169-202.

Hökelekli, H. (2011). Ailede, okulda, toplumda değerler psikolojisi ve eğitimi. İstanbul: Timaş Yayınları. 
Karagöz, B. (2009). Yapılandırmacı yaklaşıma göre ilköğretim 6 ve 7.sınıf Türkçe ders kitaplarındaki değerlerin incelenmesi (Muğla ili örneği).Muğla: Muğla Üniversitesi, Yayınlanmamış yüksek lisans tezi.

Karaman-Kepenekci, Y. ve Aslan, C. (2013). "Ortaöğretim okullarına önerilen 100 Temel Eser'deki romanlarda insan hakları üzerine bir çözümleme."Eğitim ve Bilim Dergisi, 38(168),183-197.

Karatay, H. (2007). "Dil edinimi ve değer öğretimi sürecinde masalın önemi ve işlevi."Türk Eğitim Bilimleri Dergisi,3, 463-475.

Kaymakcan, R. ve Meydan, H. (2012). "Yerel-evrensel ikileminde ilköğretim DKAB ve Sosyal Bilgiler öğretim programlarında değerler." Kuram ve Uygulamada Ĕgitim Bilimleri, 12(2), 1573-1591.

Kılcan, B. (2016). "Ignác Kúnos'un kırk dört Türk peri masalı adlı eserinin değerler açısından incelenmesi." Turkish Journal of Education (TURJE), 5(3), 82-94.

Kırmızı, F. S. (2014). "4. Sınıf Türkçe ders kitabı metinlerinde yer alan değerler." Değerler Eğitimi Dergisi, 12 (27), 217-259.

Kuçuradi, ì. (1998). Insan ve değerleri. Ankara: Türk Felsefe Kurumu Yayınları.

Kuşdil, M. E. ve Kağıtçıbaşı, Ç. (2000). "Türk öğretmenlerin değerler yönelimi ve Schwartz değer kuramı."Türk Psikoloji Dergisi, 15(45), 59-76.

Mert, E. L. (2013). "ilköğretim 6, 7 ve 8. sınıf Türkçe ders kitaplarında yer alan öykü metinlerindeki değerlerin eşdizimli sözcükler bağlamında incelenmesi."ilköğretim Online, 12 (3), 809-821.

Özdemir, E. (2017). Göğüne sığmayan bulut. Ankara: Akılçelen Kitaplar.

Öztürk, Z. (2005). "On beşinci yüzyıl şairlerinden Akşemseddinzade Hamdullah Hamdi'nin Yusuf ve Zeliha Mesnevisinde işlenen değerler."Değerler Eğitimi Dergisi, 3 (10), 43-74.

Parks, L., \& Guay, R. P. (2009). "Personality, values, and motivation."Personality and Individual Differences, 47, 675-684.

Sapsağlam, Ö. (2017). "Okul öncesi dönem çocuklarının değer algılarının çizdikleri resimler ve sözlü anlatımlarına göre incelenmesi: Sorumluluk değeri örneği." Eğitim ve Bilim, 42 (189), 287-303.

Sever, E., Memiş A., \& Sever, S. (2015). "Pertev Naili Boratav'in Zaman Zaman İçinde masal kitabının değerler açısından incelenmesi."Bartın Üniversitesi Eğitim Fakültesi Dergisi, XIV. Uluslararası Katılımlı Sınıf Öğretmenliği Eğitimi Sempozyumu (21-23 Mayıs 2015) Özel Sayısı, 246-263.

Şahin, N. (2015). Illkokul 4. sınıf Türkçe ders kitabı metinlerinin kültürel değerler açısından incelenmesi. Konya: Necmettin Erbakan Üniversitesi, Yayınlanmamış yüksek lisans tezi.

Şimşek, T. (2005). Çocuk Edebiyatı. Konya: Suna Yayınları.

Tezel, N. (2014). Türk Masalları. İstanbul: Bilge Kültür Sanat.

Ulusoy, K.,\& Dilmaç, B.(2016). Değerler Eğitimi. Ankara: Pegem Akademi.

Yavuzer, H. (2011). Çocuk psikolojisi. (33. Basım). İstanbul: Remzi Kitapevi.

Yıldırım, A., \& Şimşek, H. (2011). Sosyal bilimlerde nitel araştırma yöntemleri (8.Basım). Ankara: Seçkin Yayınları. 
Ek-1: Naki Tezel'in Türk Masallarıadlı kitabında yer alan Schwartz değer tipleri tablosu sayfa ve satır numaraları

\begin{tabular}{|c|c|c|}
\hline Değer Tipleri & Sayfa/Satır no & Toplam \\
\hline $\begin{array}{l}\text { Güç: Sosyal güç sahibi } \\
\text { olmak, otorite sahibi olmak, } \\
\text { zengin olmak, toplumdaki } \\
\text { görüntüyü koruyabilmek, } \\
\text { insanlar tarafından } \\
\text { benimsenmek. }\end{array}$ & $\begin{array}{l}\text { 24/8-9,28/22-27,(31/32-33,32/1-3),32/12-14,34/1 } \\
3-20,34 / 32-34,35 / 8-9,36 / 28,37 / 5-6,38 / 26-27,40 / 7- \\
9,54 / 19-21,56 / 10-14,60 / 12-13,62 / 24-26,70 / 27-30 \\
71 / 1-4,73 / 19-20,83 / 19-22,94 / 9-14,103 / 1-3,105 / 8 \\
112 / 4-8,112 / 14,114 / 2-3,119 / 5-6,119 / 15,145 / 30-3 \\
3,148 / 7,156 / 3-4,176 / 18-19,179 / 4-7,180 / 3-13,197 / \\
12-13,198 / 6-8,209 / 30-32,254 / 17-20,280 / 24-25,28 \\
1 / 5-7,290 / 25-26,295 / 14-17,308 / 27,315 / 4-8,319 / 5- \\
8,320 / 3-7,330 / 6-7,330 / 13-16,335 / 5-6,336 / 3-4,336 \\
/ 18-20,354 / 15-18,362 / 14-17,371 / 31-32,372 / 29-31 \\
, 386 / 2-5,394 / 10-20,417 / 30-31,421 / 3-5,421 / 17-19, \\
424 / 2-3,425 / 29-33,432 / 24-27,437 / 1-7,438 / 6-8,44 \\
9 / 17-21,449 / 29,466 / 9-10,466 / 11-12,466 / 13-16,46 \\
7 / 14-15,505 / 27-29,506 / 16-18,507 / 17-19,526 / 1-3, \\
526 / 12-14 .\end{array}$ & $75(\% 11.38)$ \\
\hline $\begin{array}{l}\text { BAŞARI:Başarılı olmak, } \\
\text { yetkin, muktedir olmak, } \\
\text { hırslı olmak, sözü geçen biri } \\
\text { olmak, zeki olmak. }\end{array}$ & $\begin{array}{l}\text { 28/13-15,(37/30-32,38/1-2),41/5-8,41/22-29,42/1 } \\
0-17,42 / 21-24,43 / 32-33,44 / 4-6,71 / 32-33,75 / 8-9,7 \\
6 / 9-11,77 / 31-32,101 / 25,110 / 26-28,112 / 11-12,113 \\
/ 31-32,114 / 9-10,114 / 28-29,118 / 17-18,119 / 9-11,1 \\
39 / 27-28,154 / 5,161 / 14-17,164 / 1-3,165 / 4-6,169 / 3- \\
5,215 / 6-10,228 / 18-20,229 / 18-19,240 / 2-3,260 / 31,2 \\
61 / 25,282 / 8-10,300 / 25-26,318 / 23-27,320 / 3-7,339 \\
/ 3-6,350 / 9-11,350 / 22-23,378 / 17-21,466 / 21-24,46 \\
7 / 6-8,468 / 31-32,473 / 3-14,(473 / 26-32,474 / 1-15), 4 \\
74 / 28-32,477 / 18-24,478 / 8-12,485 / 22-27,487 / 28-2 \\
9,491 / 19-23,492 / 12-23,(493 / 26-34,494 / 21-33,495 \\
/ 1-5),(496 / 27-33,497 / 1-4),(499 / 14-33,500 / 1-5), 50 \\
0 / 21-32,502 / 3-19,502 / 20-24,502 / 26-30,505 / 3-11, \\
505 / 14-17,505 / 21-25,506 / 14-15,507 / 15-16,507 / 22 \\
-30,508 / 3-12,508 / 13-14,509 / 10-17,522 / 6-19,524 / \\
26-34,525 / 7-16,525 / 29-30,(526 / 15-33,527 / 1-21) .\end{array}$ & $74(\% 11.22)$ \\
\hline $\begin{array}{l}\text { HAZCILIK: Zevk ve hayattan } \\
\text { tat almak. }\end{array}$ & $\begin{array}{l}\text { 26/28-29,34/1-3,36/18-20,38/18-24,39/30-31,44/7 } \\
-12,44 / 30-31,47 / 30-31,58 / 16-17,67 / 21-25,71 / 3-4 \\
73 / 26-27,75 / 4-5,75 / 11-13,76 / 5-6,76 / 13-14,77 / 19- \\
20,79 / 10,99 / 17-21,100 / 2-3,101 / 10,101 / 25,105 / 8- \\
10,108 / 17-18,108 / 25-26,(110 / 31-33,111 / 1-2), 113 / \\
30,114 / 31,118 / 5-8,119 / 21-23,143 / 18-19,145 / 19-2 \\
0,154 / 14-15,154 / 25,155 / 30-32,180 / 15-17,186 / 13- \\
15,187 / 5-6,215 / 4-5,216 / 1-2,222 / 29-30,224 / 24-27 \\
229 / 21-22,231 / 29-30,274 / 3-6,276 / 4-7,277 / 1-5,27 \\
7 / 28-30,288 / 23-27,(290 / 32,291 / 1), 309 / 7-8,321 / 8- \\
12,339 / 6-8,354 / 20-21,358 / 1-2,360 / 3-4,370 / 1,373 / \\
9-11,392 / 26-27,393 / 5-6,242 / 19-22,431 / 25-27,435 \\
/ 24-25,439 / 20-21,451 / 29-30,468 / 29-30,475 / 24-25 \\
, 484 / 22-25,487 / 29-30,503 / 19-20,508 / 14,516 / 23-2 \\
4,521 / 9-10,527 / 25-27 .\end{array}$ & $73(\% 11.07)$ \\
\hline $\begin{array}{l}\text { UYARILIM: Cesur olmak, } \\
\text { değişken bir hayat yaşamak, } \\
\text { heyecanlı bir yaşantı sahibi } \\
\text { olmak. }\end{array}$ & $\begin{array}{l}24 / 16-19,26 / 17-19,31 / 22-23,31 / 28,32 / 8-10,32 / 8-1 \\
0,32 / 16-17,39 / 26-27,44 / 28-29,47 / 20-21,60 / 21-24 \\
61 / 1-9,61 / 26-27,64 / 5-6,66 / 5-7,80 / 27-30,110 / 29-3 \\
1,112 / 9-10,112 / 17-18,118 / 25-26,124 / 28-31,131 / 1 \\
2-13,136 / 7-10,158 / 1-3,160 / 30-31,161 / 3-17,163 / 2 \\
5-28,165 / 4-6,181 / 23-27,204 / 3-4,218 / 15-16,232 / 1\end{array}$ & $45(\% 6.82)$ \\
\hline
\end{tabular}




\begin{tabular}{|c|c|c|}
\hline & $\begin{array}{l}3-15,238 / 20-21,285 / 21-25,287 / 8-10,322 / 1-4,325 / \\
32-33,342 / 5-6,343 / 14-15,344 / 2-3,401 / 25-26,422 / \\
17-19,510 / 7-8,512 / 7\end{array}$ & \\
\hline $\begin{array}{l}\text { ÖZYÖNELIM: Yaratıcı olmak, } \\
\text { merak duyabilmek, özgür } \\
\text { olmak, kendi amaçlarını } \\
\text { seçebilmek, bağımsız olmak, } \\
\text { kendine saygısı olmak. }\end{array}$ & $\begin{array}{l}24 / 16-19,26 / 13-14,26 / 17-19,31 / 28,32 / 28-29,32 / 2 \\
8-29,34 / 11,35 / 18,(35 / 31-32,36 / 1-3), 37 / 26-29,39 / 2 \\
6-27,46 / 7,46 / 20-24,47 / 20-21,48 / 14,50 / 7-9,52 / 19- \\
20,57 / 20,58 / 21-22,59 / 27-28,63 / 25,64 / 5-6,67 / 11-1 \\
3,68 / 27-30,74 / 17-18,75 / 13-17,75 / 26-27,76 / 14-18 \\
76 / 31-32,80 / 27-30,83 / 10-18,85 / 2-3,87 / 30-31,90 / 7 \\
-9,90 / 11-13,91 / 24-26,92 / 17-21,101 / 25-26,102 / 9-1 \\
1,102 / 27-32,109 / 17-18,112 / 21,112 / 23-24,120 / 14- \\
22,122 / 17-18,128 / 1-2,131 / 21,131 / 24-25,132 / 24-2 \\
7,140 / 24-25,149 / 5,157 / 21-22,179 / 20-22,181 / 6-7,1 \\
84 / 17,194 / 13-15,199 / 11-12,201 / 16-17,207 / 32,216 \\
/ 3-8,216 / 21-23,218 / 16-17,231 / 10-11,232 / 21-27,2 \\
52 / 4,255 / 24,259 / 3-4,278 / 15-17,280 / 2-3,284 / 3-7,2 \\
87 / 1-2,291 / 18-19,291 / 28-29,293 / 22-23,(297 / 30-3 \\
3,298 / 1-2), 311 / 14-15,315 / 12-15,316 / 15-16,316 / 2 \\
1-22,318 / 23-27,319 / 10-11,322 / 31-34,342 / 5-6,343 \\
/ 14-15,344 / 2-3,363 / 13-16,376 / 15-21,376 / 25-30,3 \\
78 / 1-10,386 / 9-12,386 / 28,386 / 32-33,391 / 2-6,392 / \\
18-20,395 / 21-22,397 / 13,399 / 16-20,401 / 25-26,404 \\
/ 10-11,406 / 14-15,422 / 6-7,423 / 21-23,424 / 29-30,4 \\
37 / 19-20,448 / 22-24,452 / 11,460 / 13,460 / 32-33,465 \\
/ 21-24,469 / 7-8,469 / 18,470 / 9-11,477 / 18-24,480 / 4- \\
6,489 / 3-5,501 / 16-17,518 / 27-29 .\end{array}$ & 116(\%17.60) \\
\hline $\begin{array}{l}\text { EVRENSELCiLik:Açık fikirli } \\
\text { olmak, erdemli olmak, } \\
\text { toplumsal adalet, eşitlik, } \\
\text { dünyaya barış istemek, } \\
\text { güzelliklerle dolu bir dünya, } \\
\text { doğayla bütünlük içinde } \\
\text { olma, çevreyi koruma, iç } \\
\text { uyum. }\end{array}$ & $\begin{array}{l}\text { 73/22-25,121/15-18,122/28-31,247/16-17,247/21- } \\
22,333 / 7-8,381 / 15-16,415 / 13-15,510 / 32-33\end{array}$ & $10(\% 1.51)$ \\
\hline $\begin{array}{l}\text { iYiLiKSEVERLiK: Yardımsever } \\
\text { olmak, dürüst olmak, } \\
\text { bağışlayıcı olmak, sadık } \\
\text { olmak, sorumluluk sahibi } \\
\text { olmak, gerçek arkadaşlık, } \\
\text { olgun sevgi, manevi bir } \\
\text { hayat, anlamlı bir hayat, } \\
\text { alçak gönüllü olmak. }\end{array}$ & 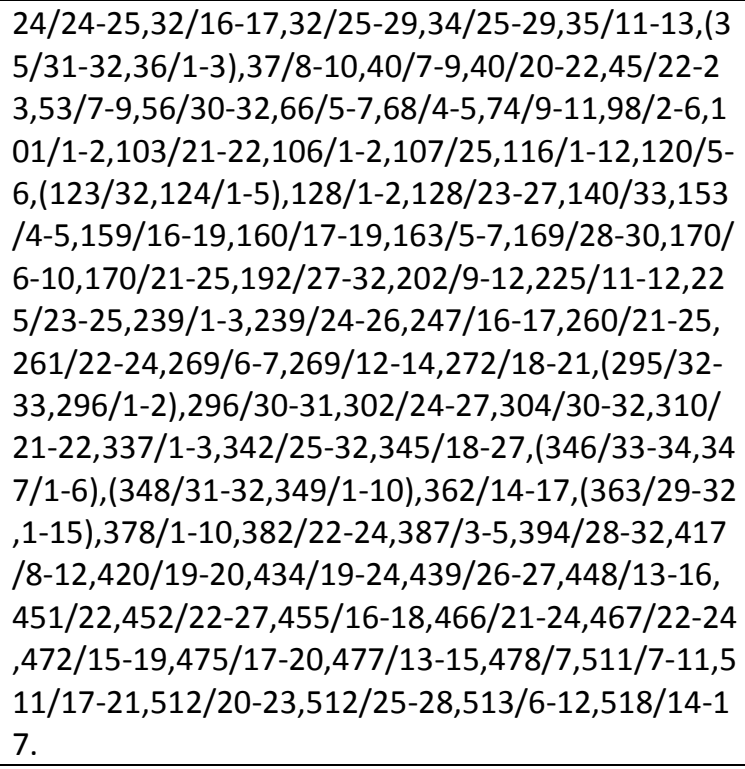 & $83(\% 12.59)$ \\
\hline $\begin{array}{l}\text { GELENEKSELLiK: } \\
\text { Alçakgönüllü olmak, dindar } \\
\text { olmak, hayatın bana }\end{array}$ & $\begin{array}{l}\text { 24/9-10,24/22-23,24/24-27,24/32-33,26/26-27,26/ } \\
31-32,27 / 26-28,28 / 5-6,28 / 13-15,28 / 20-21,30 / 1-4, \\
30 / 5-7,34 / 21-22,34 / 21-22,36 / 18-20,44 / 30-31,46 / 1\end{array}$ & 118(\%17.90) \\
\hline
\end{tabular}




\begin{tabular}{|c|c|c|}
\hline $\begin{array}{l}\text { verdiklerini kabullenmek, } \\
\text { geleneklere saygılı olmak, } \\
\text { ılımlı bir hayat. }\end{array}$ & $\begin{array}{l}\text { 5-19,47/30-31,48/9,54/7-13,58/1-3,58/15-17,62/2 } \\
4-26,62 / 30-32,63 / 7-9,63 / 15-17,67 / 15-16,69 / 19-22 \\
, 73 / 26-27,74 / 21,75 / 11-13,75 / 30-31,76 / 12-14,79 / 4 \\
-10,80 / 1-2,82 / 8-9,82 / 11-12,84 / 26-27,87 / 26-29,90 / \\
5-6,93 / 3-5,99 / 14-21,100 / 13,103 / 28-32,107 / 18-19, \\
113 / 29-30,114 / 31,147 / 5,151 / 24,155 / 30-32,156 / 3- \\
4,156 / 9-10,158 / 1-3,158 / 20-21,159 / 26-27,162 / 17- \\
18,164 / 28-29,172 / 16-17,174 / 30-31,176 / 12,186 / 11 \\
-15,187 / 5-6,193 / 19-22,206 / 5-7,215 / 4-5,215 / 10,22 \\
2 / 29-30,224 / 23-24,229 / 21-22,231 / 29-30,234 / 11-1 \\
2,237 / 28,241 / 17-18,245 / 16,246 / 8,252 / 30-32,253 / \\
15-16,288 / 23-25,290 / 25-26,298 / 3-4,306 / 9-10,309 \\
/ 7-8,324 / 9-11,339 / 6-7,354 / 20-21,356 / 6-7,358 / 1-2, \\
358 / 27-29,363 / 18-19,370 / 1,371 / 27,373 / 9-11,375 / \\
14-15,376 / 1-8,388 / 6-7,392 / 26-27,400 / 15-16,401 / \\
6-7,407 / 28-29,410 / 10-11,410 / 18-20,411 / 4,411 / 11 \\
-13,420 / 20-21,424 / 19-22,431 / 25-27,435 / 24-25,43 \\
9 / 31,451 / 24-25,451 / 29-30,454 / 8-9,456 / 19,460 / 21 \\
-22,465 / 31-33,468 / 29-30,475 / 22-25,479 / 12-17,48 \\
7 / 29-30,516 / 23-24,527 / 25-26 .\end{array}$ & \\
\hline $\begin{array}{l}\text { UYMA: Kibarlık, itaatkar } \\
\text { olmak, anne babaya ve } \\
\text { yaşlılara değer vermek, } \\
\text { kendini denetleyebilmek. }\end{array}$ & $\begin{array}{l}\text { 26/7-8,27/4-6,27/26-28,28/20-21,44/7-12,62/24-2 } \\
6,79 / 11-13,82 / 2-3,101 / 1-2,119 / 12,141 / 11-18,158 / \\
1-3,159 / 26-27,172 / 16-17,174 / 30-31,176 / 12,193 / 2 \\
2-23,234 / 11-12,252 / 20-21,298 / 3-4,344 / 2-3,358 / 2 \\
7-29,363 / 18-19,371 / 27,375 / 14-15,410 / 18-20,411 / \\
4,411 / 11-13,411 / 27,420 / 19-20,422 / 6-7,424 / 13-14, \\
454 / 17-19,456 / 19,460 / 20-22,474 / 26-27,479 / 20 .\end{array}$ & $40(\% 6.06)$ \\
\hline $\begin{array}{l}\text { GÜVENLIK: Ulusal güvenlik, } \\
\text { toplumsal düzenin } \\
\text { sürmesini istemek. Temiz } \\
\text { olmak, aile güvenliği, iyiliğe } \\
\text { karşılık vermek, bağlılık } \\
\text { duygusu, sağlıklı olmak. }\end{array}$ & $\begin{array}{l}24 / 12-14,35 / 5-6,36 / 1-3,54 / 7-13,63 / 11-13,67 / 15-1 \\
6,70 / 2-3,94 / 9-14,98 / 18-24,115 / 3-6,169 / 18-20,228 \\
/ 7-15,278 / 9-10,278 / 12-14,288 / 12-13,294 / 12-15,3 \\
30 / 13-14,365 / 3-5,365 / 10-12,365 / 17-19,365 / 24-28 \\
, 381 / 10-11,408 / 15-17,467 / 25-26,478 / 13,(512 / 31- \\
33,513 / 1-4) .\end{array}$ & $25(\% 3.79)$ \\
\hline TOPLAM & & 659 \\
\hline
\end{tabular}

